\title{
Merging two variables (observational learning and self-talk), is not preference one variable evermore
}

Azimi Panah.S. (M.A). University of Tehran, Tehran, Iran

Tahmasebi Boroujeni, S. (Ph.D). University of Tehran, Tehran, Iran

Received: 2016 - $11-7$

Accept: $2017-9-12$

\section{Abstract}

Observing a model let learners to make a plan of action that can be used for learning motor skills. Moreover, self-talk is a conversation that performers use it either apparently or secretly in order to think about their performance and reinforce it. Therefore, the purpose of this study was to investigate the effect of observational learning, self-talk and combination of both on boy's performance. The statistical samples of the present study included 60 students $(12.25 \pm 1.24)$ with forth and fifth grade that were selected as available subjects. After volleyball AAHPERD pre-test, subjects divided into 6 groups: Instructional self-talk (STI), motivational self-talk (STM), observational learning (OB), combination of Instructional self-talk and learning observation (STI-OB), combination of motivational self-talk and observational learning (STM-OB) and control group (CO) and during one day, they were participated in specific intervention that planed for each group. On the first day of intervention, subjects participated in acquisition phase and acquisition test was taken, after 48 hours' retention and transfer test was Held. In each phase of study self-efficacy was examined. The results of two-way ANOVA revealed that there was a significant difference among all training groups with control group $(p \leq 0.05)$. These results support the use of cognitive factors, self-talk and observational learning and the combination of observational learning and Instructional self-talk as learning facilitator.

Keywords: Instructional self-talk, Motivational self-talk, Volleyball Service, Observational learning 


\title{
تأثير خودَفتارى، يادكيرى مشاهدهاى و تركيب آن بر خودكار آمدى و مهارت سرويس واليبال
}

\author{
سجاد عظيمى بناه*، شهزاد طهماسبى بروجنى 1**

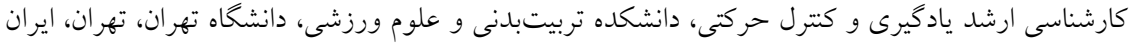

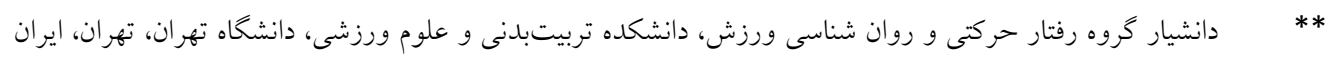

مشاهده يكى مدل به يادكيرنده امكان شكل دادن طرحى از عمل مىدهد. همجنين، خودكفتارى مكالمهاى است كه

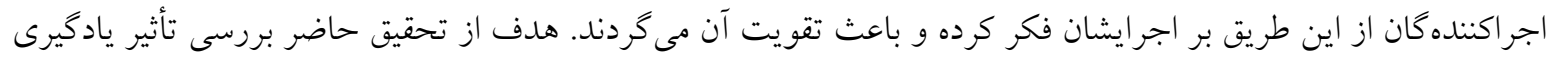

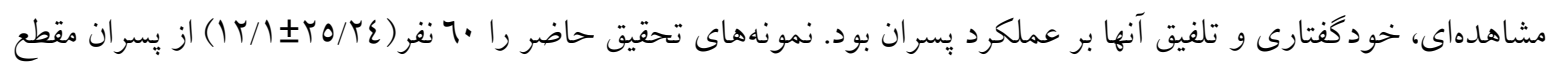

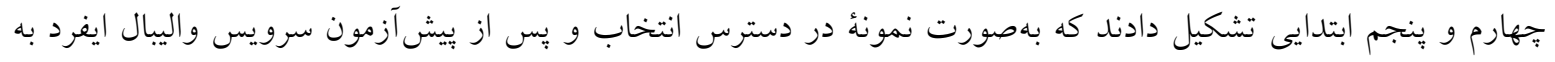

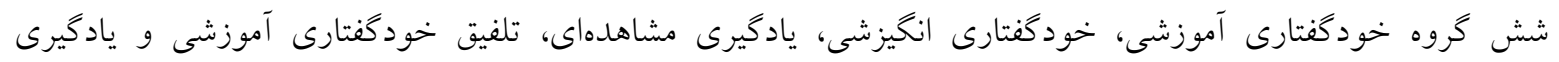

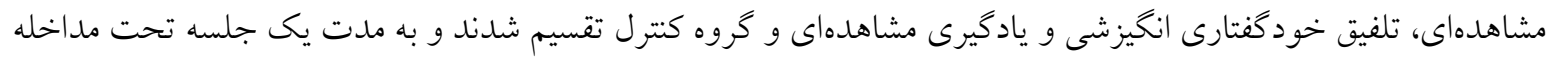

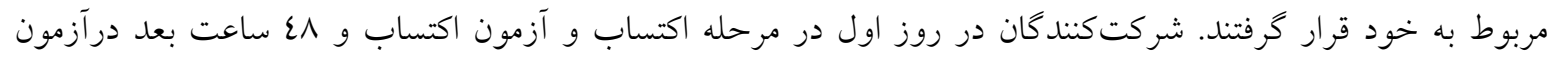

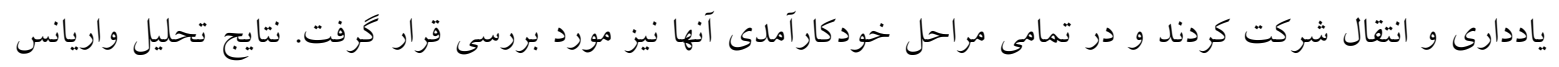

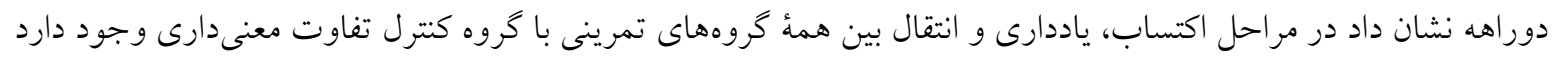

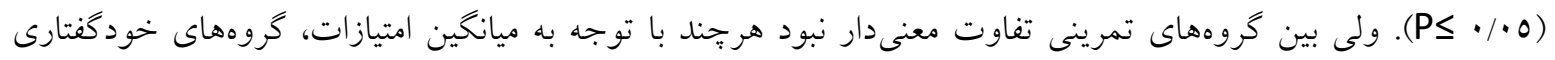

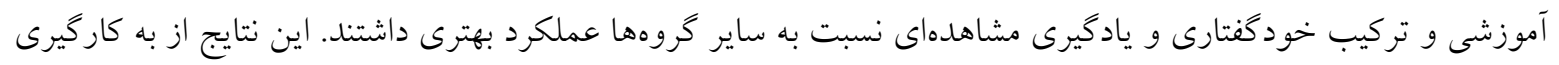

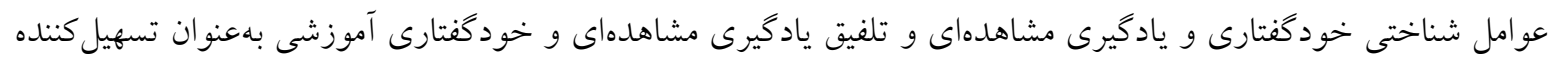
يادكيرى حمايت مى كند. وازههاى كليدى: خودكفتارى آموزشى، خودكفنتارى انخَيزش، سرويس واليبال، يادكيرى مشاهدهاى. 


\section{مقدمه}

يادگيرى يكى از بخشهاى مهم زندگى انسان محسوب مىشود (1)، و اين باور نيز وجود دارد، كه تمرين بدنى تنها روش ياد كيرى و كسب مهارتهاى جديد نيست (Y). يكى از اهداف اصلى يادكيرى حركتى، شناخت متغيرهاى مستقلى است كه ميزان يادكيرى را بالا برده، يا يادكيرى را مختل مى كنند ( (). از جمله اين متغيرها، روشهاى تمرينى مختلف براى آموزش مهارتهاى حركتى است و ازآنجا كه بيشتر مهارتها شامل عوامل بدنى و شناختى است، در نتيجه بيشنهاد شده كه علاوه بر تمرين بدنى، مداخلههاى شناختى مانند خود كفتارى'و تمرين مشاهدهاى ' نيز مى تواند يادگيرى مهارتها را تسهيل كند (rا، ع). تمرين بدنى يكى از روشهاى سنتى و رايج بر اى آموزش مهارتهاى حركتى است كه از ديرباز تاكنون مورد توجه بوده است. اما واضح است كه استفاده از تمرين بدنى صرف در همة موقعيت هاى يادكيرى مقدور نيست. براى مثال هنخامى كه ورزشكار، آسيبديده و قادر به تمرين جسمانى نيست، يا زمانى كه بيمار سكتهُ مغزى در دوران نقاهت به سر مىبرد و قادر به حركت مؤثر بدنى نيست، تمرين بدنى شيوه تمرينى مناسبى نخواهد بود. تحقيقات كسترداى نشان دادهاند كه يادكيرى مشاهدهاى (0) و خودكفتارى (ع) جزء عواملى هستند، كه بر يادگيرى مهارتهاى حركتى تأثير كذاشته و اجراى مهارت را بهبود مىبخشند. ياد گيرى مشاهدهاى فرآيندى است كه از طريق آن مشاهدهر رفتار فرد ديخرى را مشاهده كرده، و رفتار خود را با آن سازكار مىنمايد (7)، كه مىتواند از طريق مشاهده الخوى زنده (مبتدى يا ماهر)، الخوى ويديوئى (فيلم يا عكس)، ويا الخودهى كامبيوترى (انيميشن) اتفاق بيفتد. از اين ميان نيز تأييد شده است كه الكودهى زنده بر يادگيرى مهارت حركتى مؤثرتر است (V). همجينين تأثير كذارى بيشتر مشاهده الكوى در حال يادكيرى كه همراه با آكاهى از نتيجه باشد نسبت به الكوى ماهر به تأييد رسيده است (1) در زمينه يادگيرى مشاهدهاى، نظرئٌ شناختى اجتماعى باندروا (باندورا،

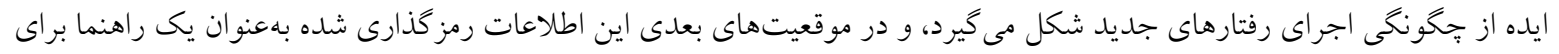
عمل استفاده مى شود. به عقيده باندورا در ياد گيرى مشاهدهاى جهار زير فرآيند مجزا وجود دارد: توجه، ياددارى، بازسازى و انخيزش (1). اين جهار فرآيند با هم تركيب شده تا بازنمايى شناختى از عمل مشاهده شده شكل دهند. اين بازنمايى بهعنوان راهنمايى براى اجراى مهارت و معيارى براى كشف و اصلاح خطا به كار مىرود (rا, 7). به طور كلى، مشاهدهُ حركت با فراهم كردن محركهاى واضح مربوط به اجراى تكليف، در ايجاد بازنمايى حركت مؤثر است و استفاده از مشاهده حركت در موقعيتهاى يادكيرى مهارتهاى دشوار

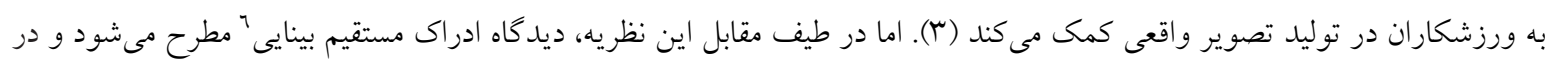
اين جشمانداز عقيده بر اين است كه خود عمل به طور مستقيم درى مىشود و نيازى به واسطةٌ شناختى براى تبديل مشاهده به عمل

وجود ندارد و دستخاه بينايى قادر است اطلاعات بينايى را به طور خودكار بردازش نمايد (9). در اين راستا، خط سير نتايج تحقيقات مبين آن است كه مشاهده اجر اى ديخران مىتواند موجب بهبود عملكرد كودى در استفاده از ابزار

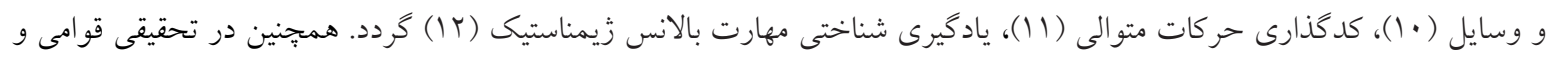
همكاران ( (1) (1)، تأثير مشاهده مدل انيميشنى، تصاوير ثابت و مدل تركيبى بر يادكيرى حركتى مهارت بالانس دو بِيه را بررسى كردند

$$
\text { نتايج از تأثير كذارى مشاهده الكو حكايت داشت (V). }
$$

يكى ديخر از رايجترين استراتزيىهاى قابل استفاده براى بهبود اجراى مهارت حركتى خود خفتارى است. خود خفتارى، جماتى است كه ورزشكار حين اكتساب يا اجر اي مهارت، بهطور ناخودآكاه يا دلبهخواهى با خود تكرار مى كند كه مىتواند آرام و درونى يا با صداى بلند باشد به كونهاى كه كسانى كه در آن نزديكى هستند صدا را بشنوند، با اينكه هدف خود ورزشكار است نه افرادى كه مشاهدهر هستند (سا). بهطور كلى خود گفتارى رويكردى ذهنى است كه بهطور ناخودآكاه بر احساسات، عمل و رفتار فرد تأثير مى گذارد (ع).

1. Self-talk

2. Observational learning

3 . Live modeling
4. Video modeling

5 . Social learning theory of Bandura (1986)
6. Direct perception view of vision

or 
خود كفتارى داراى دو نوع عملكرد آموزشى و انكيزشى است، خودكفتارى آموزشى (مج دست)، تكنيكها و تاكتيكهاى جهتدارى

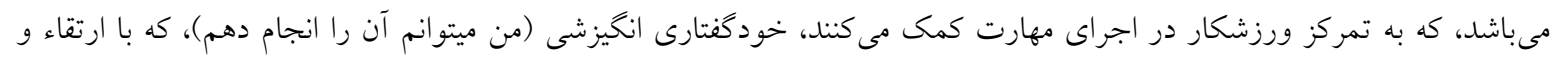

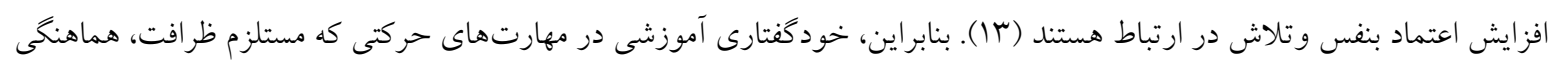

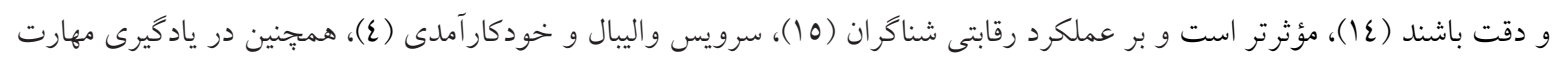

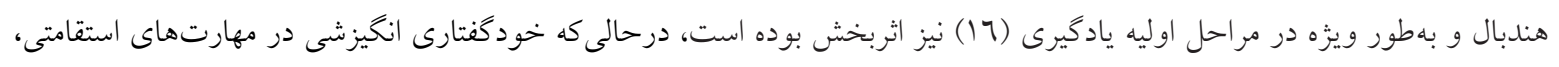

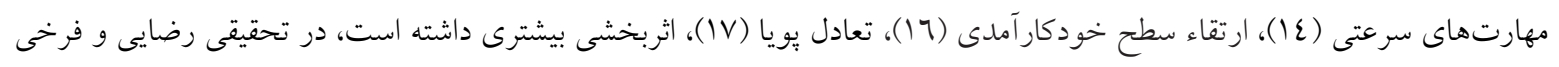

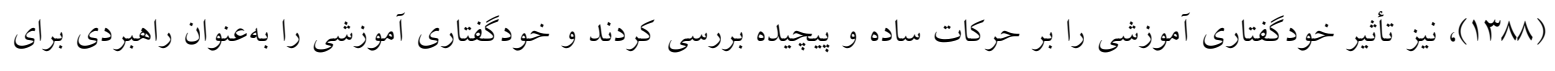

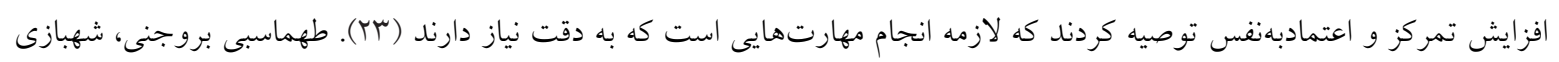

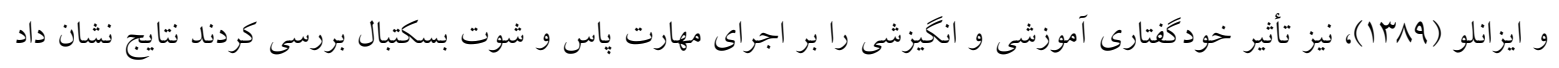

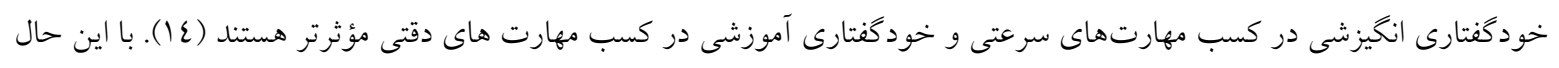

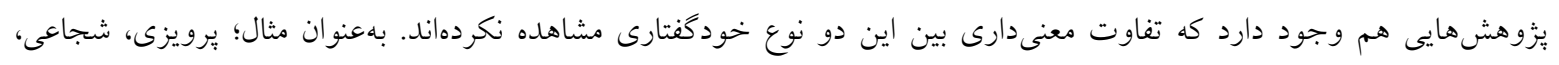

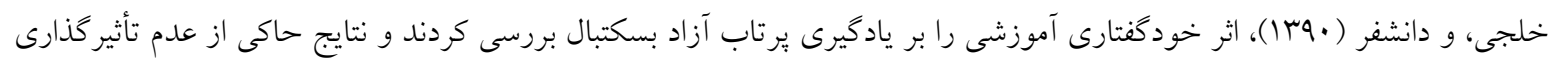

خود كفتارى بر يادكيرى بود (19).

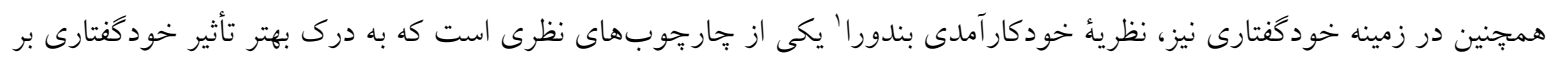

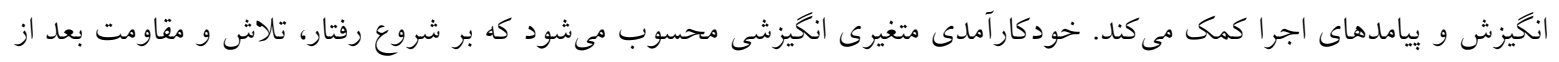

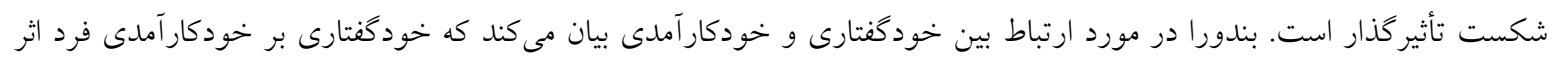

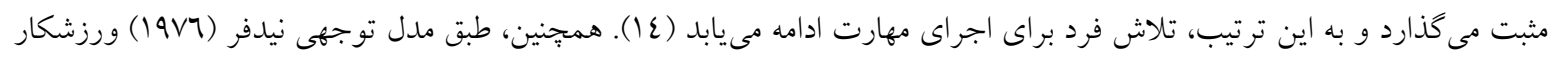

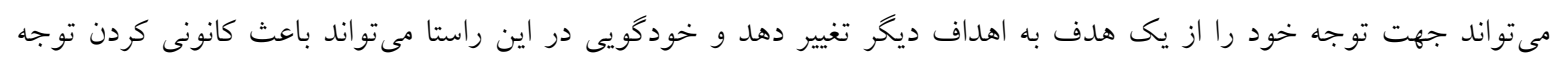

$$
\text { ورزشكار شود (19). }
$$

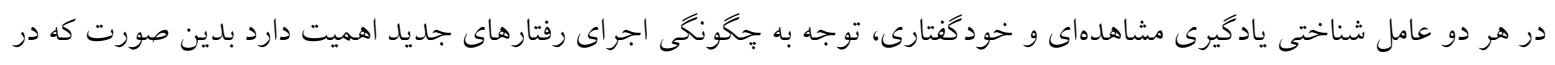

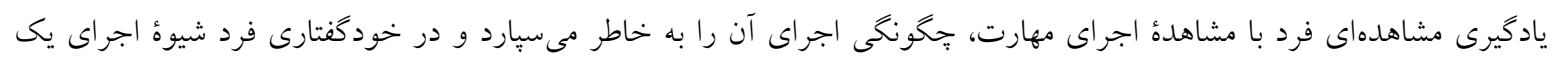

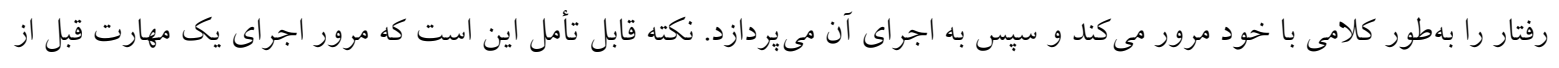

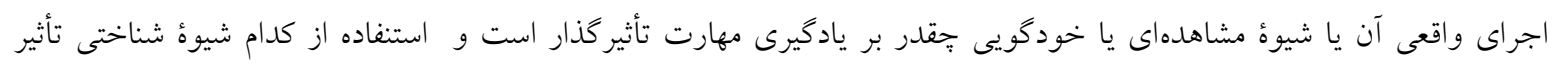

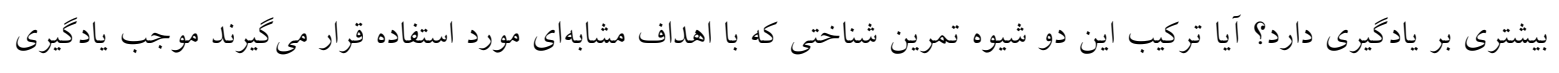

بيشتر خواهد شد؟ همان طور كه ذكر شد در بيشتر تحقيقات بهطور جداگانه به اثربخشى يادكيرى مشاهدهاى و خودكفتارى در يادكيرى مهارتها يرداخته

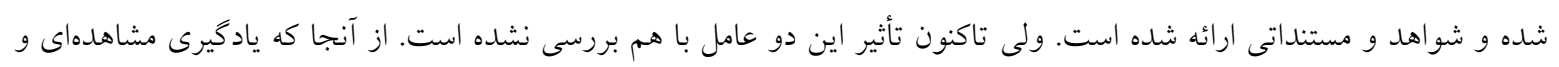

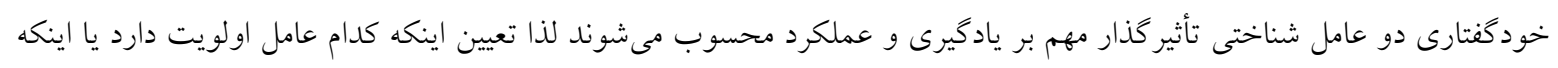

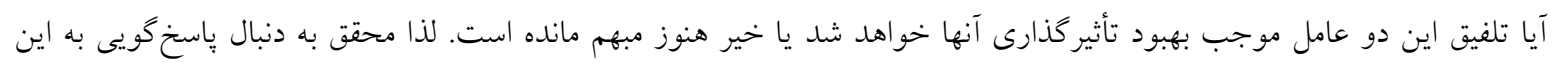

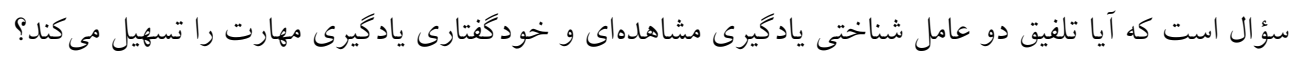

\section{روشاسنى}

تحقيق حاضر از نوع نيمهتجربى و به لحاظ هدف كاربردى بود. طرح تحقيق نيز به صورت بيش آزمون- بسآزمون بود. 


\section{شركتكندكان}

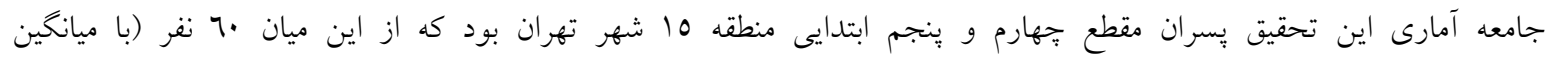

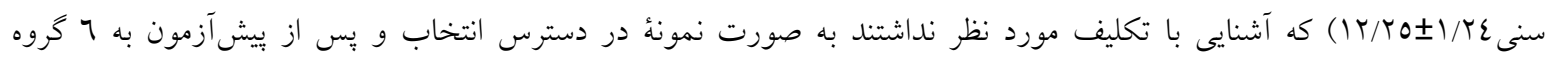

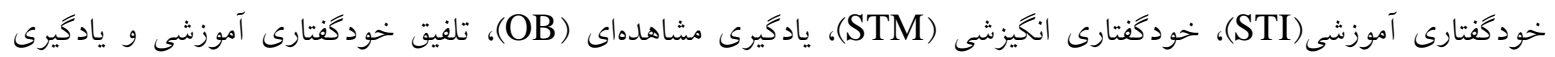

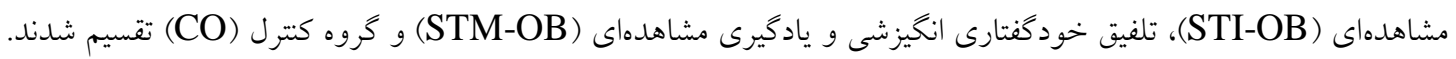

ابزار جمع آورى اطلاعات

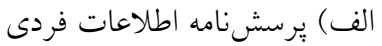

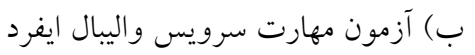

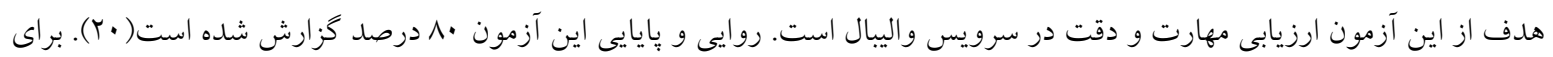

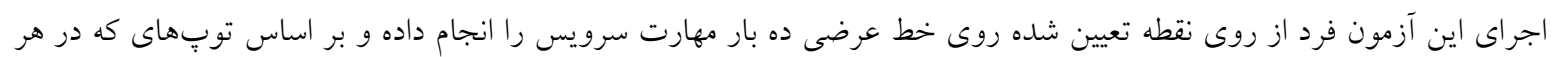

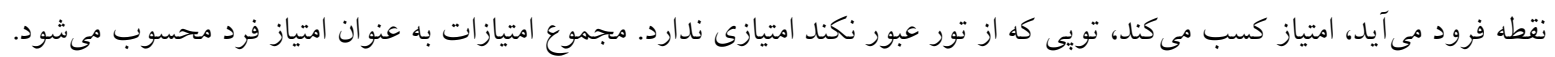

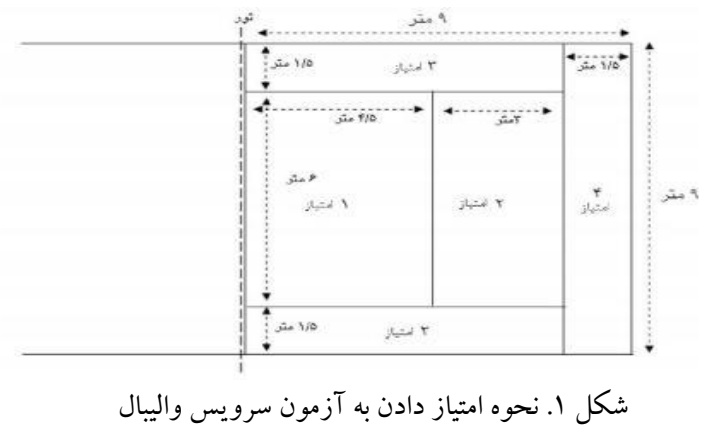

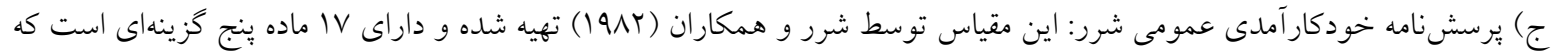

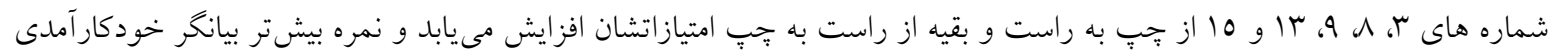

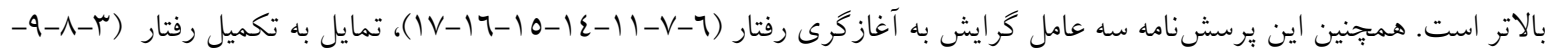

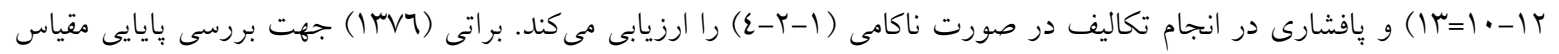

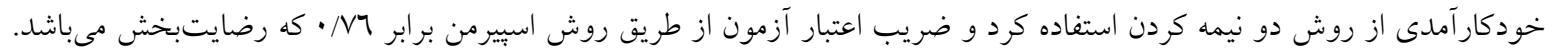

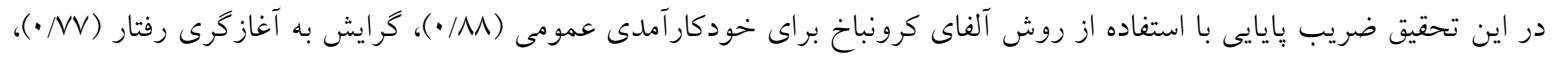

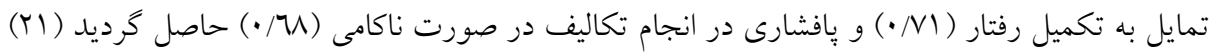

\section{روش اجراى تحقيق}

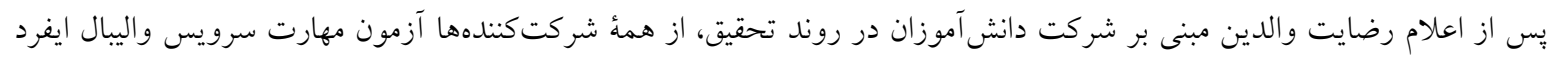

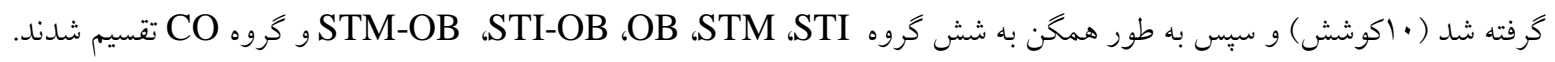

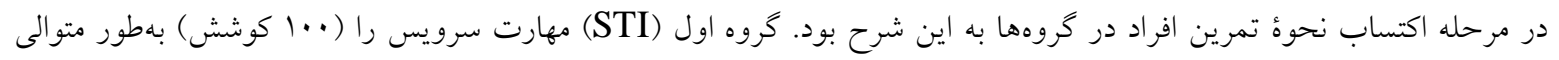

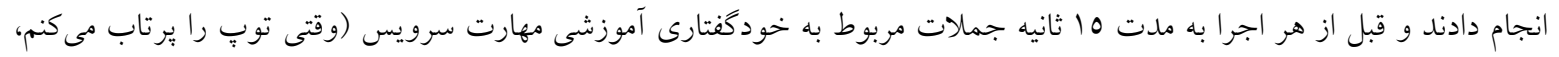

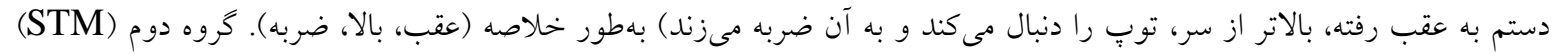

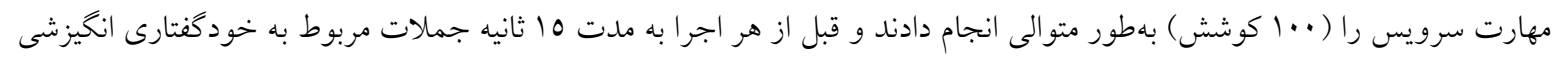


(من مى توانم بهترين امتياز را بخيرم) را تكرار مى كردند. كروه سوم (OB) كروه تمرين مشاهدهاى بودند كه .. أسوشش از اجراى كروه

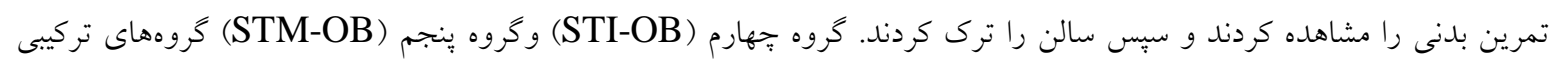

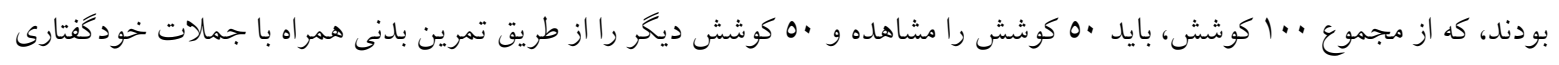

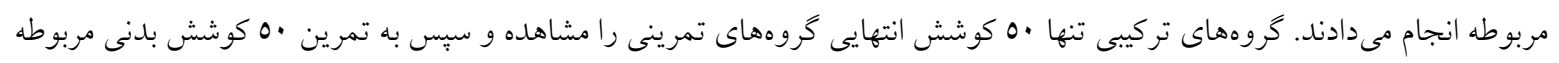

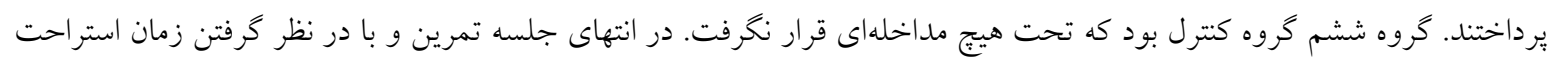

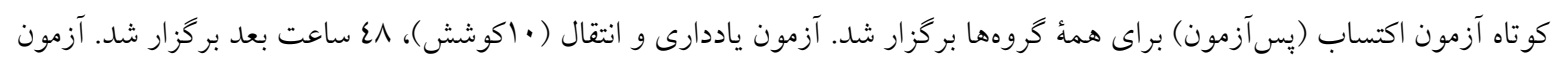

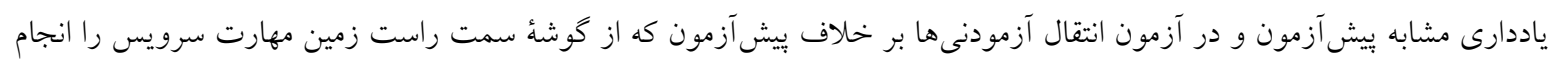

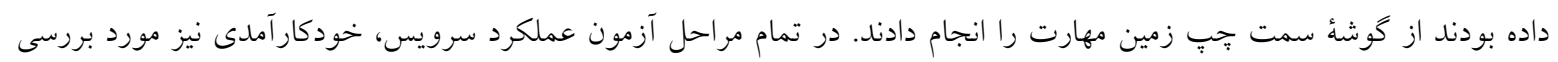
قرار كرفت.

\section{روشهاى آمارى}

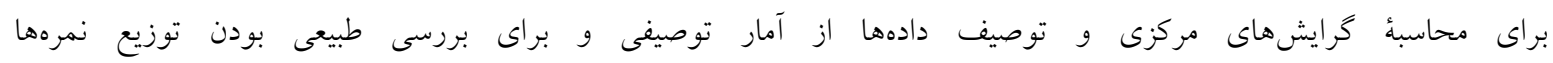

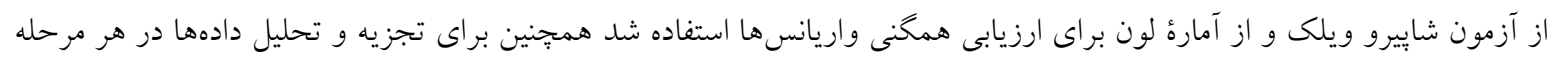

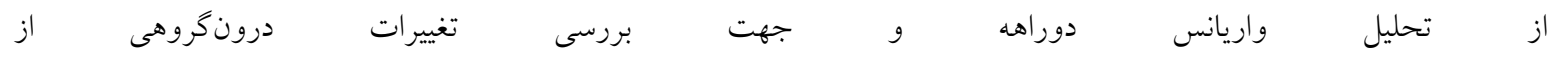

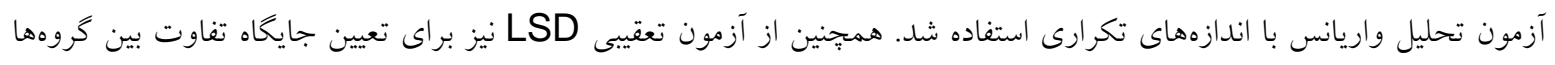

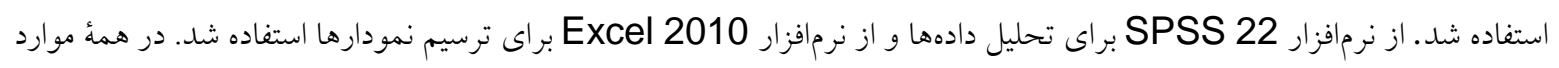

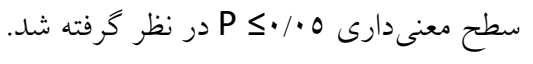

يافته هاى تحقيق

ميانخين و انحراف استاندارد كروههاى تحقيق به تفكيك مراحل در جدول شمارة ا كزارش شده است.

جدول ا. ميانكين و انحر اف استاندارد گروههاى تحقيق به تفكيك مراحل

\begin{tabular}{|c|c|c|c|c|c|c|}
\hline $\mathrm{CO}$ & OB & STM-OB & STI-OB & STM & STI & كروهها \\
\hline $10 / \cdots \pm r / r q$ & $10 / \mu \pm 1 / N$. & $10 / V \cdot \pm \varepsilon / r_{q}$ & $10 / 9 \cdot \pm r / 90$ & $1 \varepsilon / 9 \cdot \pm r / 7 r$ & $17 / r \cdot \pm r / 1 r$ & ييشآزمون \\
\hline $\mid \varepsilon / r \cdot \pm r / r_{0}$ & $19 / 1 \cdot \pm r / r \varepsilon$ & $r \cdot / \Lambda \cdot \pm 1 / r_{0}$ & $r T / r \cdot \pm \varepsilon / \cdot r$ & $r q / 1 \cdot \pm r / V 7$ & $T r / r \cdot \pm r / r q$ & يس آزمون \\
\hline$|r / V \cdot \pm r / r|$ & $|V / \Lambda \cdot \pm| / 7 \mid$ & $I V / A \cdot \pm Y / 70$ & $r M / \neg \cdot \pm 0 / \Lambda r$ & $r / / r \cdot \pm \varepsilon / \cdots$ & $r 0 / \Lambda \cdot \pm 0 / 29$ & ياددارى \\
\hline $1 r / V \cdot \pm r / v q$ & $17 / \varepsilon \cdot \pm 1 / \varepsilon r$ & $1 \Lambda / \cdots \pm r / V \varepsilon$ & $r \mu / \tau \cdot \pm \varepsilon / T \varepsilon$ & $r I / 0 . \pm r / V \varepsilon$ & $r Y / r \cdot \pm 0 / \cdot 0$ & انتقال \\
\hline
\end{tabular}

براى مقايسه تأثير يادكيرى مشاهدهاى و خود كفتارى بر يادكيرى مهارت سرويس واليبال از آزمون تحليل واريانس دوراهه استفاده شد.

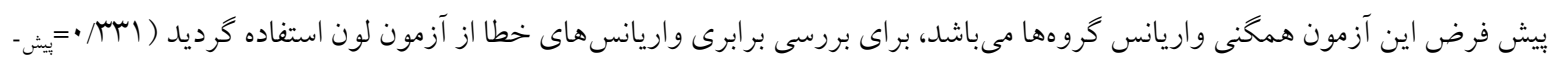

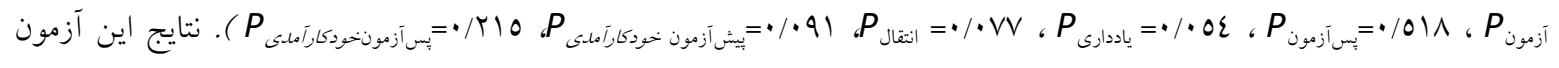

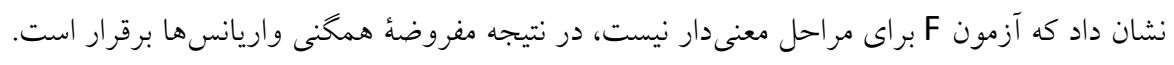




\begin{tabular}{|c|c|c|c|c|c|c|}
\hline $\mathbf{P}$ & $\mathbf{F}$ & مجانكين & درجة آزادى & جمع مجذور ها & مراحل & \\
\hline.$/ 19 \varepsilon \cdot 1$ &.$/ 1 r q$ & T/OAV & $0 \varepsilon$ & I T/9M & بيش آزمون & \\
\hline $1 / N r x^{19-1}$. & $r q / \cdot 1 r$ & $\varepsilon \cdot 7 / 70 \mathrm{~V}$ & $0 \varepsilon$ & r.MT/rAr & يس آزمون & كروههاى \\
\hline $0 / r^{M} x^{q-1}$ & $1 r / r 09$ & 190/RT. & $0 \varepsilon$ & $9 \vee 7 / 7 \ldots$ & ياددارى & تمرينى \\
\hline $1 / \cdot 7 x^{1 \cdot-1} \cdot$ & $1 \varepsilon / \varepsilon 7 \varepsilon$ & $r 1 . / 19$. & $0 \varepsilon$ & $1.0 . / 90$. & انتقال & \\
\hline
\end{tabular}

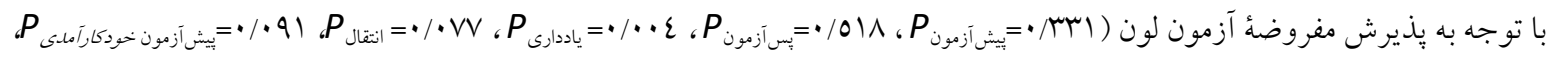

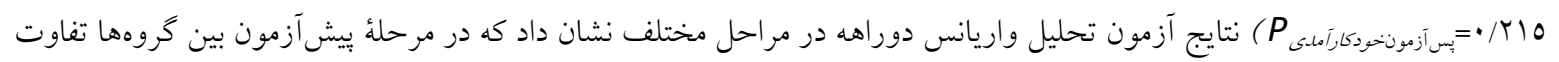

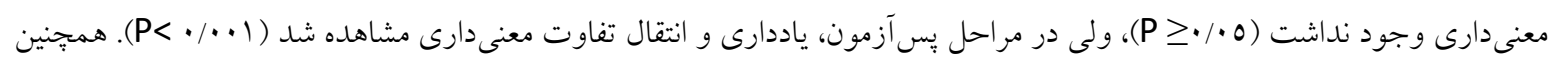

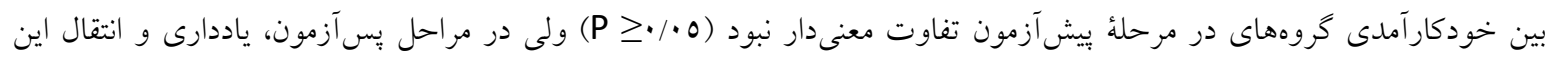

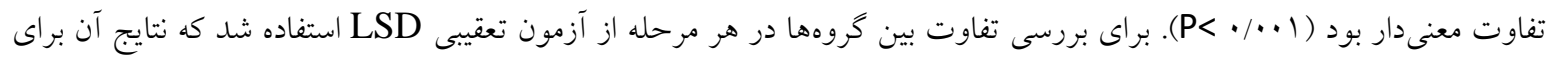

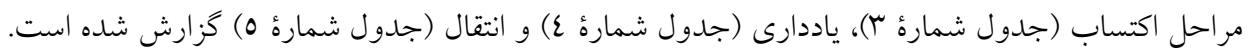

جدول r. نتايج آزمون تعقيبى LSD در مرحلةً اكتساب

\begin{tabular}{|c|c|c|c|c|c|}
\hline معنى دارى & اختلاف ميانكينها & خطاى استاندارد & \multicolumn{2}{|c|}{ كروه } & مرحله \\
\hline $\begin{array}{l}* \bullet / \cdots 1 \\
* / . r \varepsilon \\
* \bullet / \ldots \\
* \bullet / \ldots \\
* / \ldots\end{array}$ & $\begin{array}{l}T / \cdot . \\
r / \mid . \\
11 / \varepsilon . \\
\mid r / \varepsilon . \\
\mid V / \cdot .\end{array}$ & $\begin{array}{l}1 / 7 V \varepsilon \\
1 / 7 V \varepsilon \\
1 / 7 V \varepsilon \\
1 / 7 V \varepsilon \\
1 / 7 V \varepsilon\end{array}$ & $\begin{array}{c}\text { STI-OB } \\
\text { STM } \\
\text { STM-OB } \\
\text { OB } \\
\text { CO }\end{array}$ & STI & \\
\hline $\begin{array}{l}\cdot / \cdot r \varepsilon \\
* \bullet / \cdot r \\
* \bullet / \cdots 0 \\
* / \cdots\end{array}$ & $\begin{array}{l}r / 9 . \\
0 / \varepsilon . \\
7 / \varepsilon . \\
11 / \cdot\end{array}$ & $\begin{array}{l}1 / 7 V \varepsilon \\
1 / 7 V \varepsilon \\
1 / 7 V \varepsilon \\
1 / 7 V \varepsilon\end{array}$ & $\begin{array}{c}\text { STM } \\
\text { STM-OB } \\
\text { OB } \\
\text { CO }\end{array}$ & STI-OB & اكتساب \\
\hline 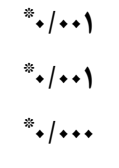 & $\begin{array}{l}\Lambda / \mu . \\
9 / \mu . \\
1 \pi / q .\end{array}$ & $\begin{array}{l}1 / 7 V \varepsilon \\
1 / 7 \vee \varepsilon \\
1 / 7 V \varepsilon\end{array}$ & $\begin{array}{c}\text { STM-OB } \\
\text { OB } \\
\text { CO }\end{array}$ & STM & \\
\hline $\begin{array}{l}\cdot / V \& \Delta \\
* / \cdot+r\end{array}$ & $\begin{array}{l}1 / \cdot \cdot \\
0 / 7 .\end{array}$ & $\begin{array}{l}1 / 7 V \varepsilon \\
1 / 7 V \varepsilon\end{array}$ & $\begin{array}{l}\text { OB } \\
\mathrm{CO}\end{array}$ & STM-OB & \\
\hline$* * 1 \cdot \bullet 1$ & $\varepsilon / 7$. & $1 / 7 V \varepsilon$ & $\mathrm{CO}$ & $\mathrm{OB}$ & \\
\hline
\end{tabular}

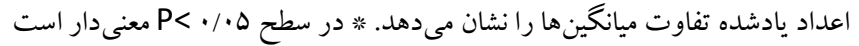

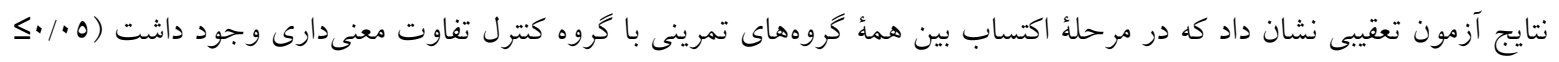

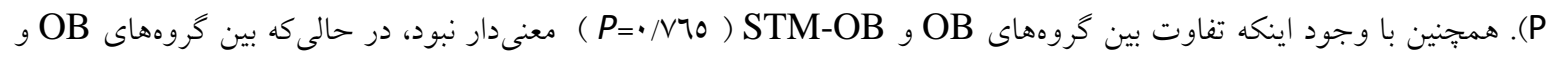


تفاوت معنى دارى وجود داشت ( STI-0B

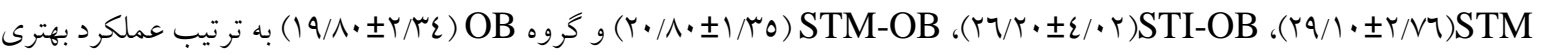
در اين مرحله داشتهاند.

جدول F. نتايج آزمون تعقيبى LSD در مر حلة ياددارى

\begin{tabular}{|c|c|c|c|c|c|}
\hline معنى دارى & اختلاف ميانكينها & خطاى استاندارد & \multicolumn{2}{|c|}{ كروه } & مرحله \\
\hline $\begin{array}{l}\cdot / Y Y I \\
* / \bullet \mid \varepsilon \\
* \bullet / \ldots \\
* \bullet / \ldots \\
* \bullet / \ldots\end{array}$ & $\begin{array}{l}r / r . \\
\varepsilon / 0 . \\
N / \cdot \cdot \\
N / \cdot \cdot \\
\mid r / 1 .\end{array}$ & $\begin{array}{l}1 / V V A \\
1 / V V A \\
1 / V V A \\
1 / V V A \\
1 / V V A\end{array}$ & $\begin{array}{c}\text { STI-OB } \\
\text { STM } \\
\text { STM-OB } \\
\text { OB } \\
\text { CO }\end{array}$ & STI & \\
\hline $\begin{array}{l}\cdot / r+1 \\
* \bullet / \cdot r \\
* / \cdots r \\
* / \cdots r\end{array}$ & $\begin{array}{l}r / \Gamma . \\
0 / A . \\
0 / A . \\
9 / 9 .\end{array}$ & $\begin{array}{l}\text { I/VVA } \\
\text { I/VVA } \\
\text { I/VVA } \\
\text { I/VVA }\end{array}$ & $\begin{array}{c}\text { STM } \\
\text { STM-OB } \\
\text { OB } \\
\text { CO }\end{array}$ & STI-OB & ياددارى \\
\hline $\begin{array}{l}* 1 . F F \\
* 1 . F F \\
* 1 . .\end{array}$ & $\begin{array}{l}r / 0 . \\
r / 0 . \\
V / 7 .\end{array}$ & $\begin{array}{l}\text { I/VVA } \\
\text { I/VVA } \\
\text { I/VVA }\end{array}$ & $\begin{array}{c}\text { STM-OB } \\
\text { OB } \\
\text { CO }\end{array}$ & STM & \\
\hline $\begin{array}{l}1 / \cdot \bullet \\
* \bullet \cdot r\end{array}$ & $\begin{array}{l}\cdot / \cdot \cdot \\
\varepsilon / 1 .\end{array}$ & $\begin{array}{l}\text { I/VVA } \\
\text { I/VVA }\end{array}$ & $\begin{array}{l}\mathrm{OB} \\
\mathrm{CO}\end{array}$ & STM-OB & \\
\hline$* / . r$ & $\varepsilon /$. & I/VVA & $\mathrm{CO}$ & $O B$ & \\
\hline
\end{tabular}

اعداد يادشده تفاوت ميانكين ها را نشان مىدهد. * در سطح ه./PS معنىدار است

همجنين با توجه به نتايج آزمون LSD در مرحلة ياددارى بين همد كروههاى تمرينى با گروه كترل تفاوت معنىدارى وجود داشت

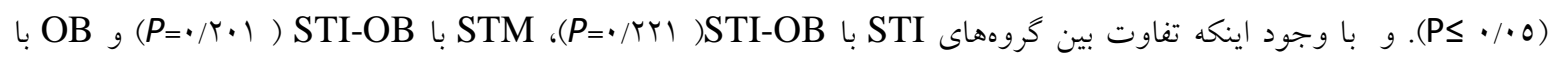

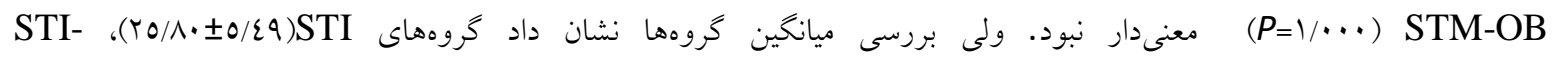

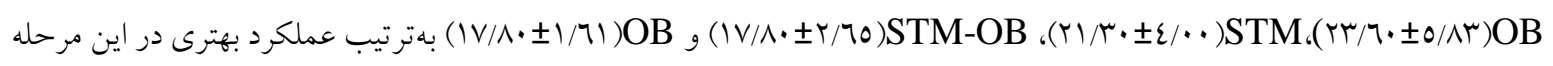
داشتهاند.

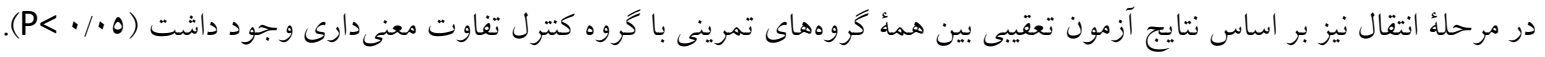

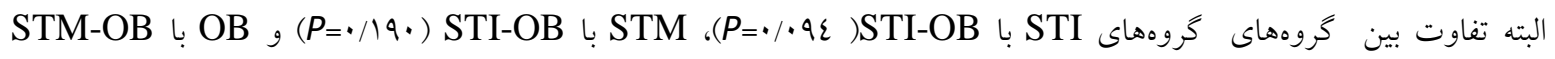

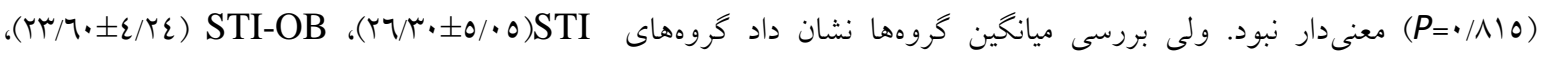

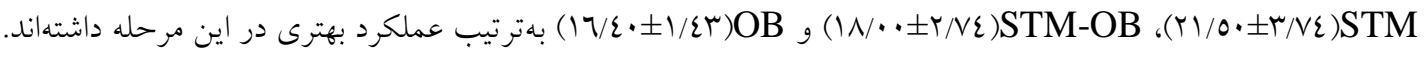


جدول ه. نتايج تعقيبى LSD در مرحلة انقال

\begin{tabular}{|c|c|c|c|c|c|}
\hline معنى & اختلاف ميانكينها & خطاى استاندارد & \multicolumn{2}{|c|}{ كروه } & مرحله \\
\hline $\begin{array}{l}\bullet / 9 \varepsilon \\
* / \cdots \varepsilon \\
* \bullet \cdots \\
* \bullet \ldots \\
* \bullet \ldots\end{array}$ & $\begin{array}{l}r / 1 . \\
\varepsilon / \Lambda . \\
\Lambda / r . \\
V / q . \\
\mid r / 7 .\end{array}$ & $\begin{array}{l}1 / V \cdot 0 \\
1 / V \cdot 0 \\
1 / V \cdot 0 \\
1 / V \cdot 0 \\
1 / V \cdot 0\end{array}$ & $\begin{array}{c}\text { STI-OB } \\
\text { STM } \\
\text { STM-OB } \\
\text { OB } \\
\text { CO }\end{array}$ & STI & \\
\hline $\begin{array}{l}\bullet / 19 . \\
* / \cdots 1 \\
* / \cdots 1 \\
* .1 \ldots\end{array}$ & $\begin{array}{l}Y / V . \\
T / Y . \\
0 / 1 . \\
1 \cdot 10 .\end{array}$ & $\begin{array}{l}1 / V \cdot 0 \\
1 / V \cdot 0 \\
1 / V \cdot 0 \\
1 / V \cdot 0\end{array}$ & $\begin{array}{c}\text { STM } \\
\text { STM-OB } \\
\text { OB } \\
\text { CO }\end{array}$ & STI-OB & انتقال \\
\hline 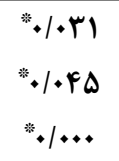 & $\begin{array}{l}r / 0 . \\
r / 1 . \\
V / \Lambda .\end{array}$ & $\begin{array}{l}1 / V \cdot 0 \\
1 / V \cdot 0 \\
1 / V \cdot 0\end{array}$ & $\begin{array}{c}\text { STM-OB } \\
\text { OB } \\
\text { CO }\end{array}$ & STM & \\
\hline $\begin{array}{l}. / 110 \\
* / .+9\end{array}$ & $\begin{array}{l}\cdot / \varepsilon . \\
\varepsilon / \mu .\end{array}$ & $\begin{array}{l}1 / V \cdot 0 \\
1 / V \cdot 0\end{array}$ & $\begin{array}{l}\mathrm{OB} \\
\mathrm{CO}\end{array}$ & STM-OB & \\
\hline$* / \cdot . p$ & $\varepsilon / v$. & $1 / N \cdot 0$ & $\mathrm{CO}$ & $\mathrm{OB}$ & \\
\hline
\end{tabular}

براى بررسى بيشرفت گروهها از مرحلة بيش آزمون تا مرحلةُ ياددارى و انتقال از آزمون تحليل واريانس با اندازههاى تكرارى استفاده

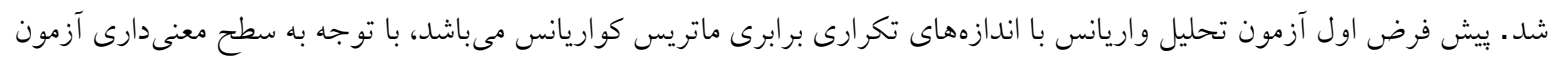

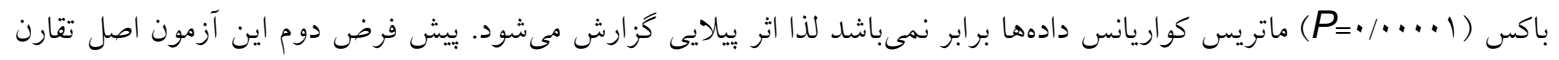

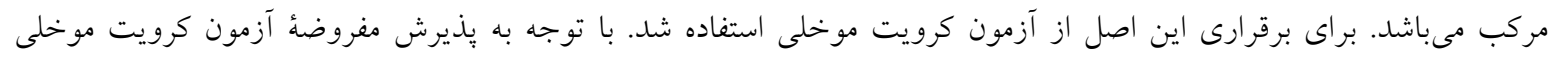
(X) (O)=VV/•19 ، P=•/IV)

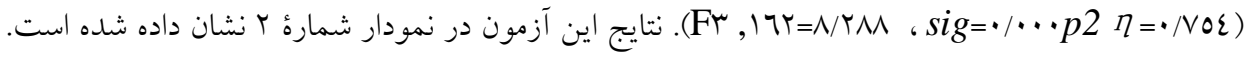




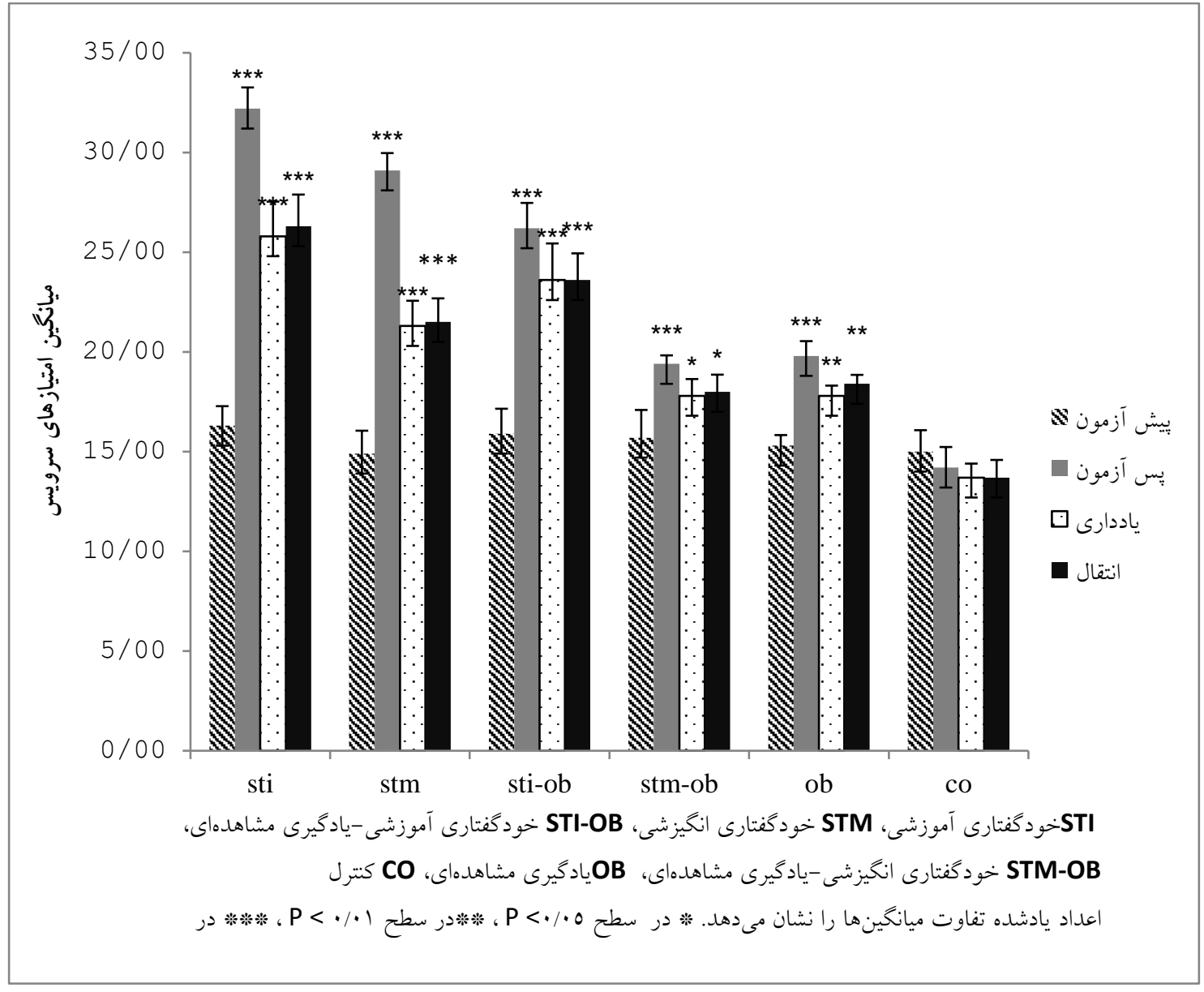

شكل r. عملكرد گروهها در بيش آزمون، بِ آزمون، ياددارى و انتقال

هدف از تحقيق حاضر بررسى تأثير خودكفتارى آموزشى و انخيزشى، يادگيرى مشاهدهاى و تلفيق آنها بر يادكيرى مهارت سرويس

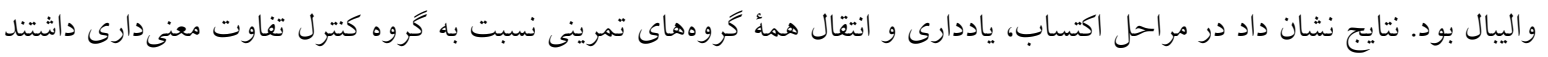

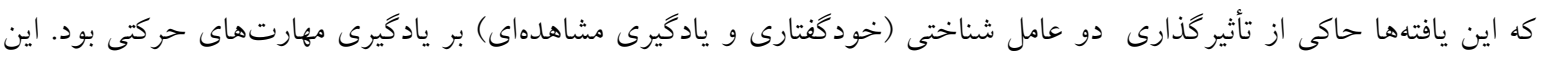

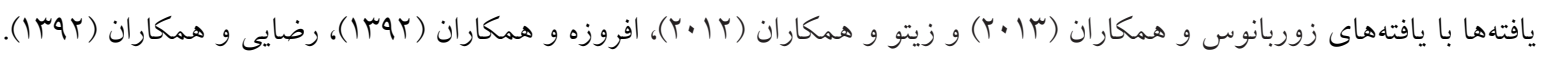

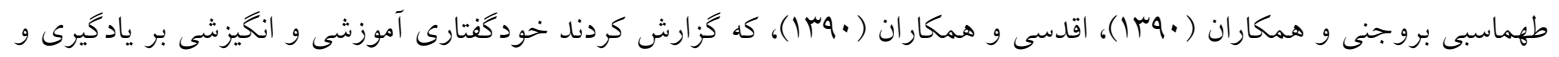

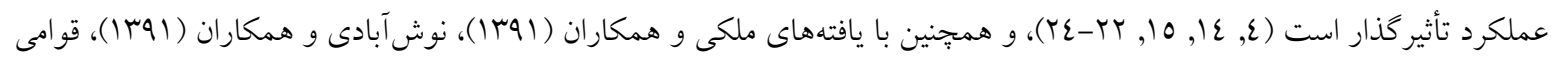

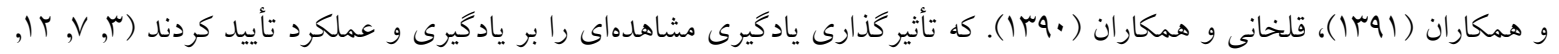

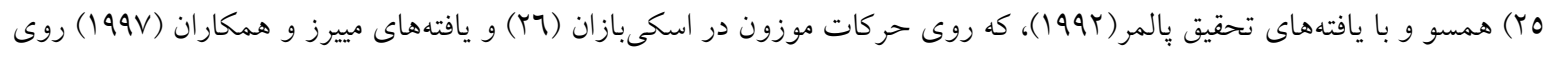

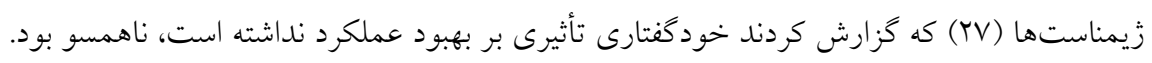

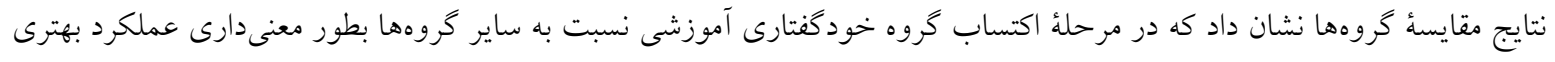

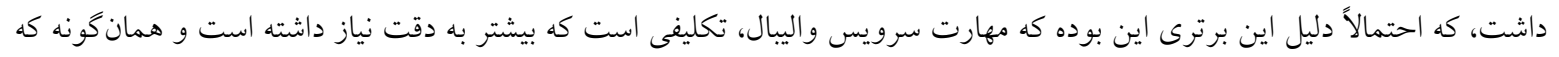

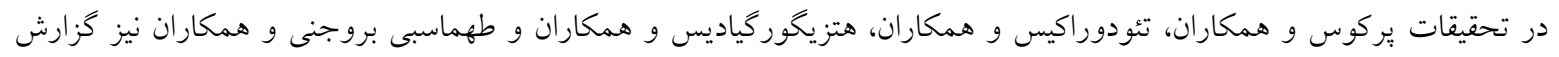

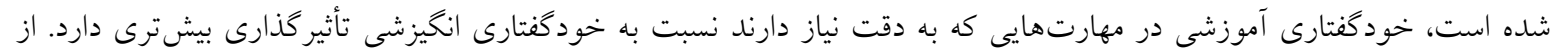




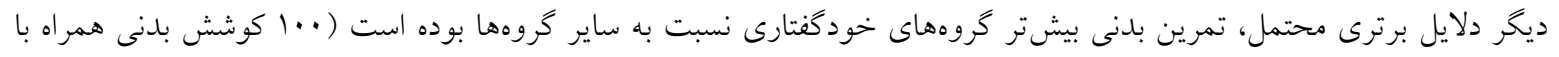

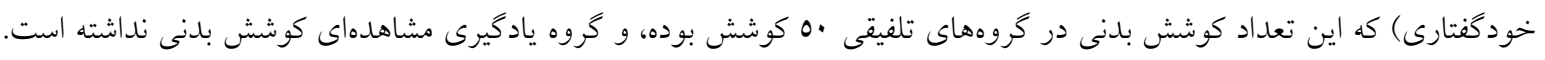

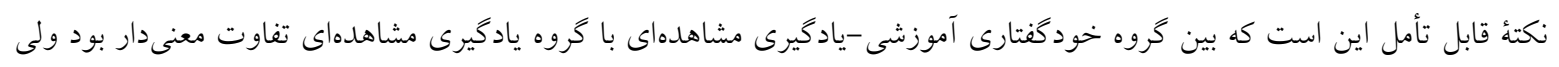

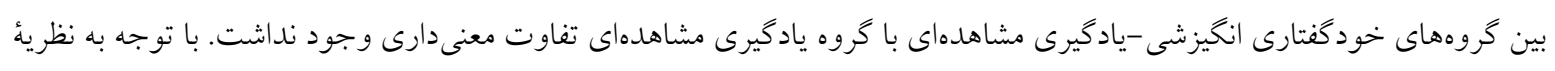

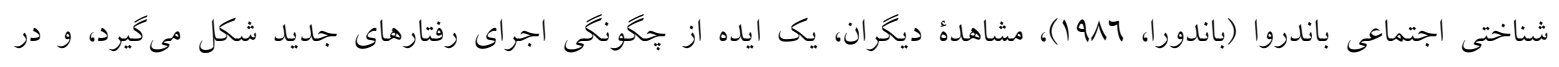

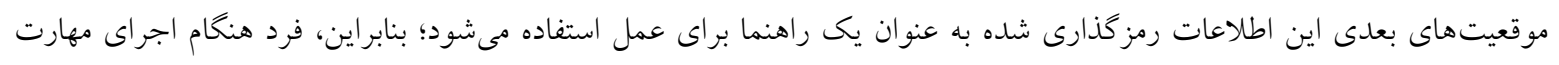

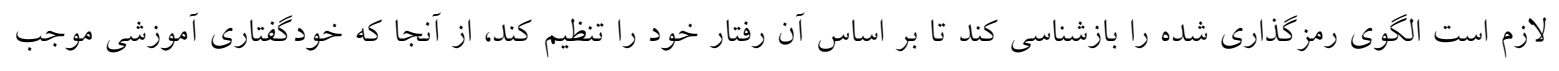

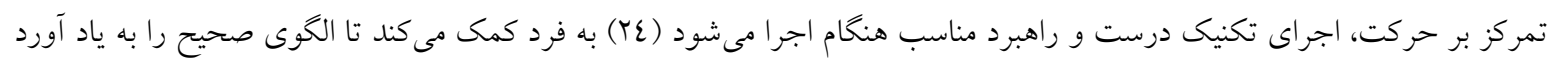

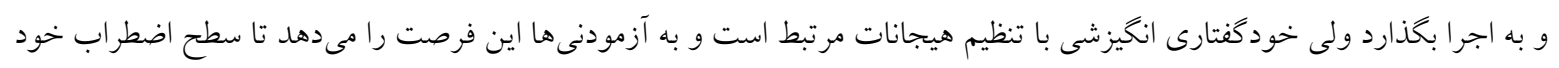

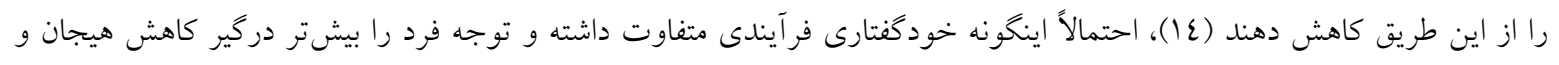

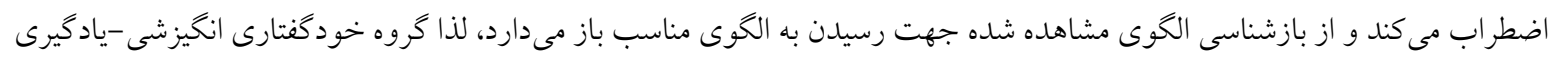
مشاهدهاى عملكرد خوبى نداشته است.

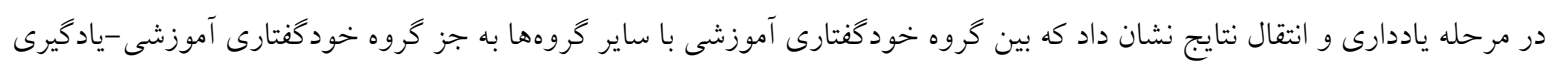

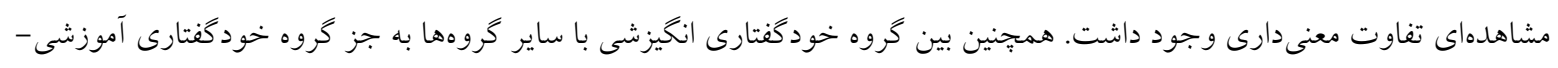

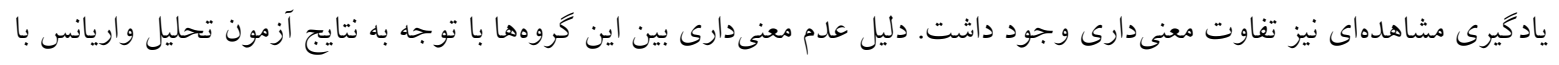

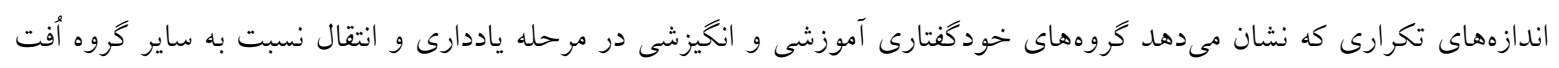

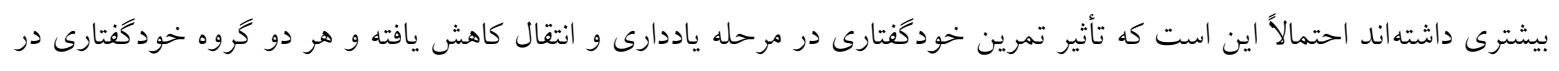

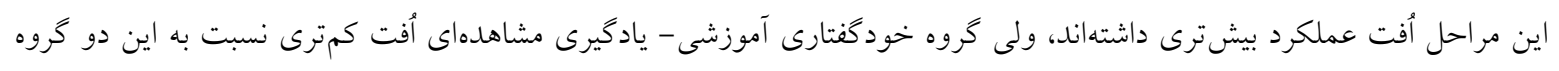

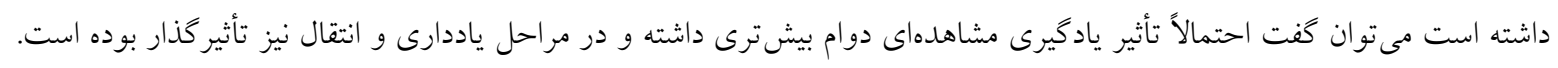

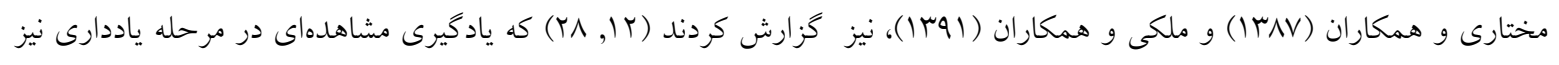

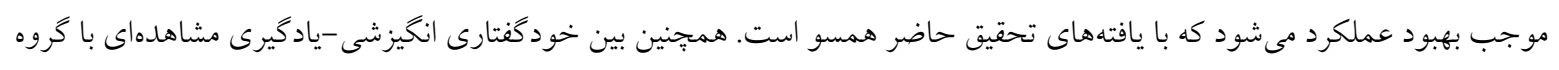

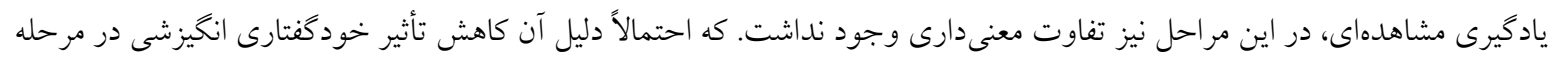

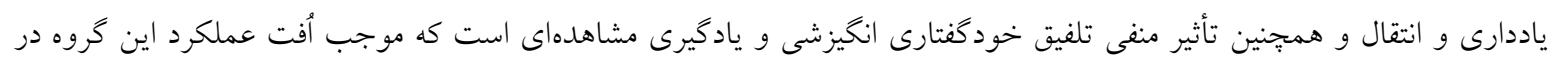

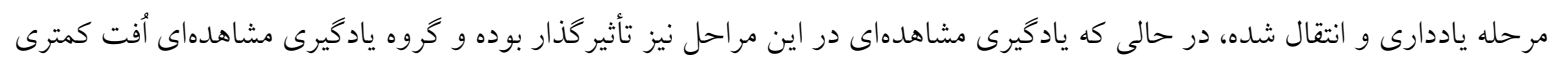
را متحمل شده است.

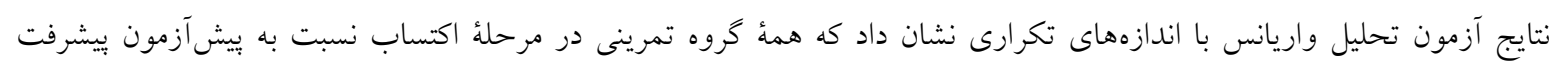

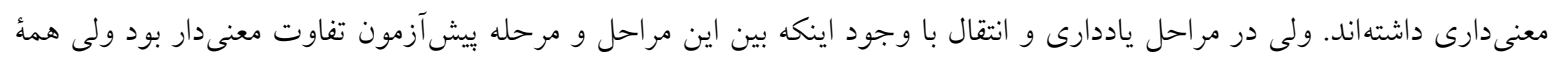

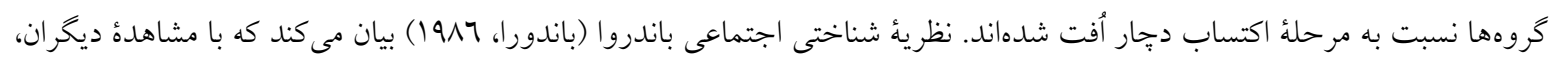

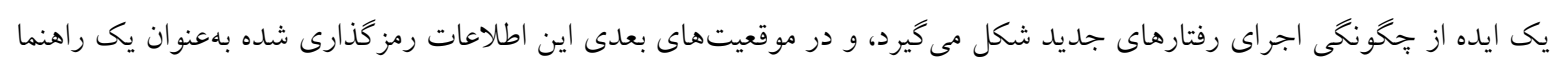

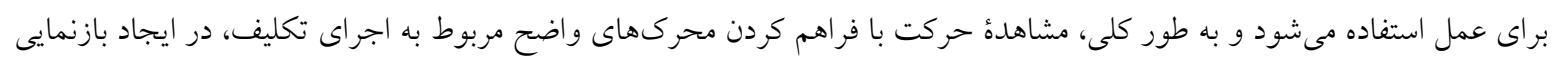

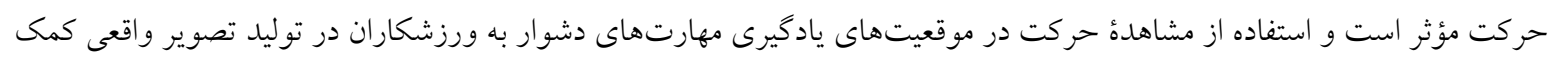

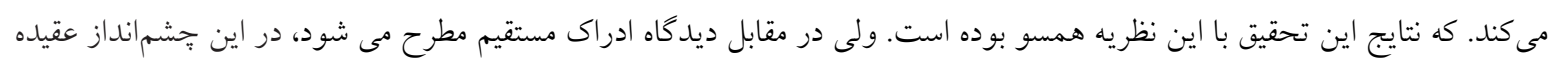

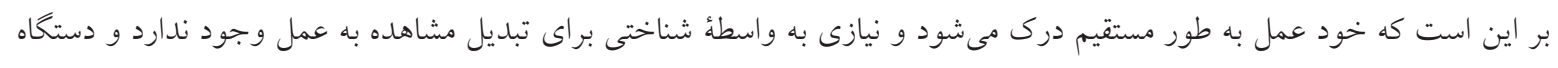

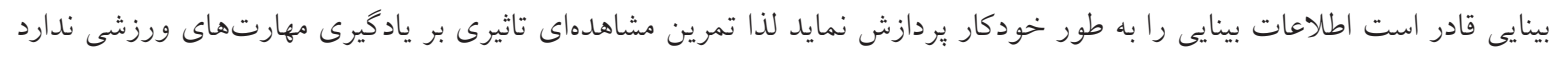

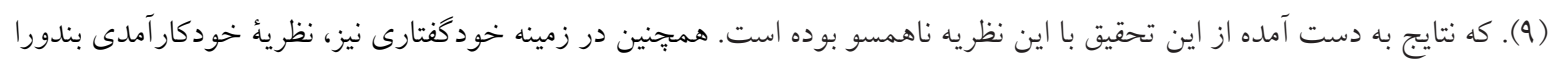


بيان مى كند كه خودكار آمدى متغيرى انخيزشى محسوب مى شود كه بر شروع رفتار، تلاش و مقاومت بعد از شكست تأثير كذار است.

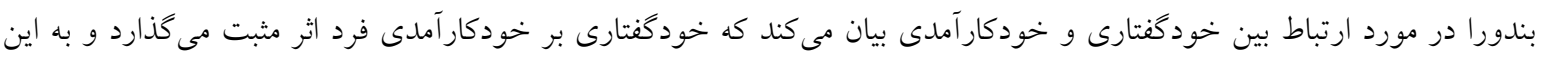

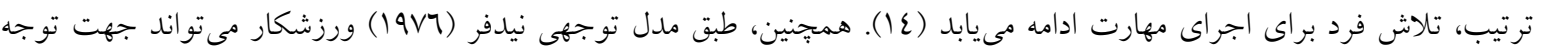

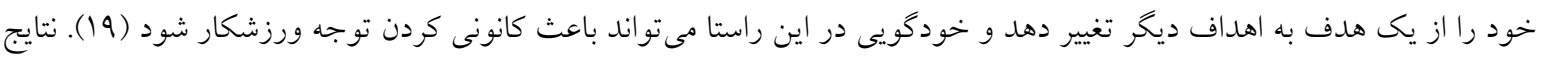

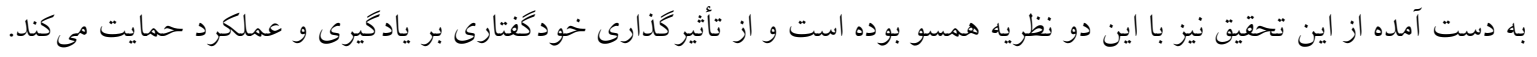

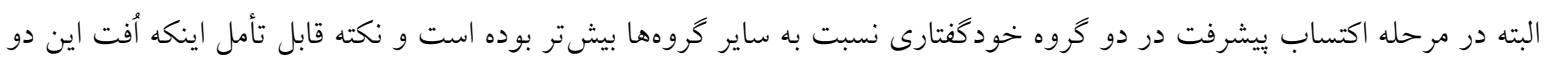

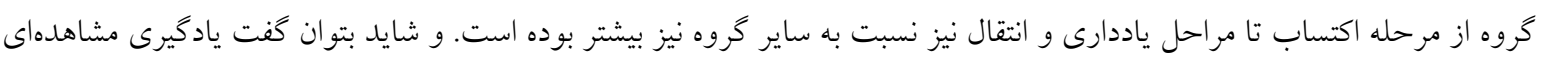

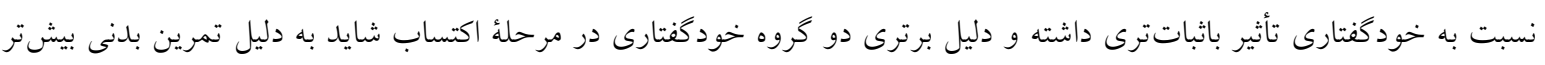

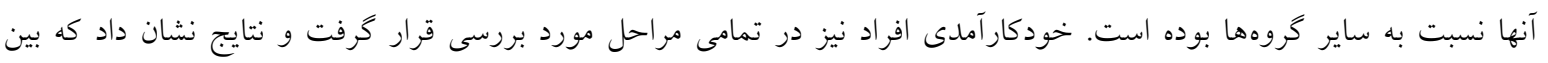

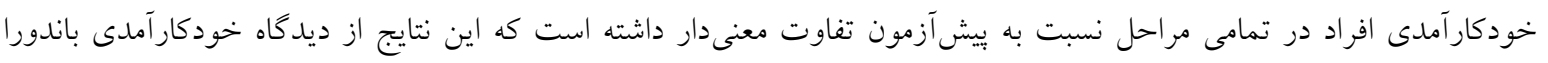

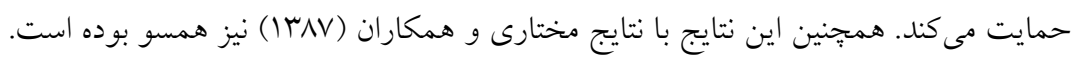

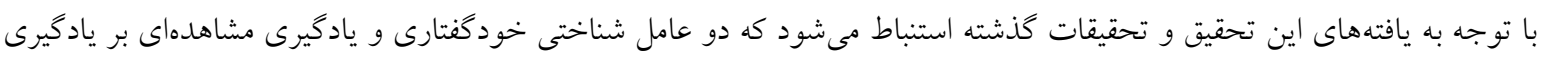

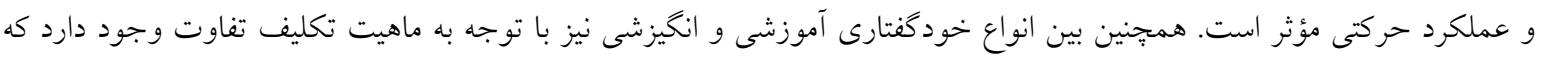

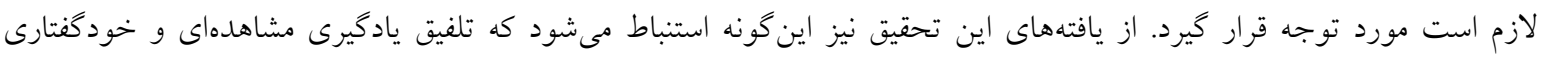

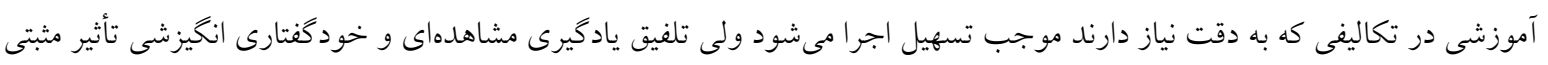

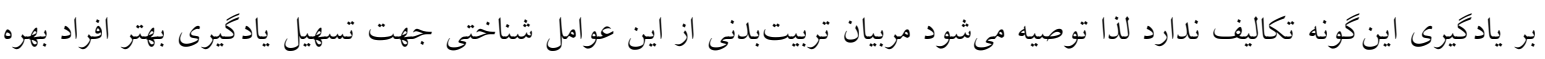

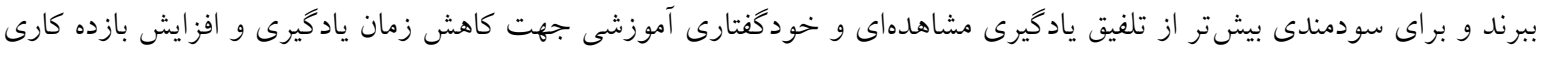

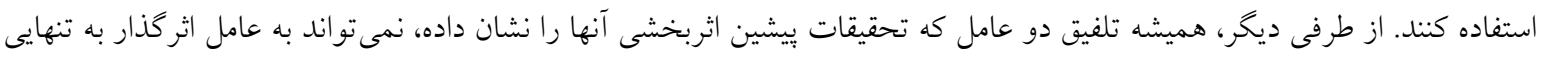

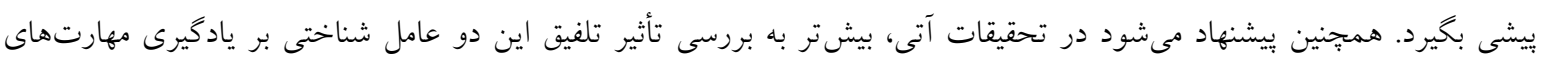

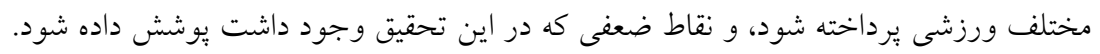

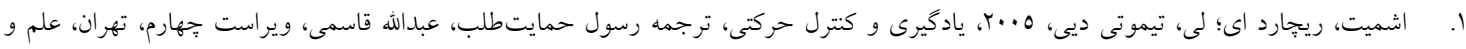

$$
\text { حركت، }
$$

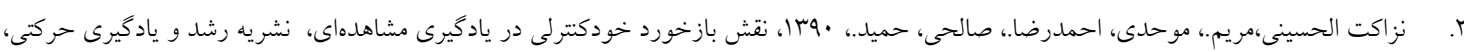

شماره V، ص: 1.1-1-10

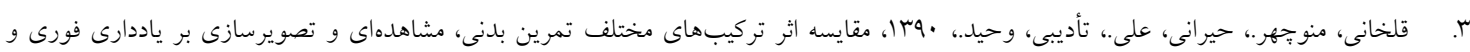

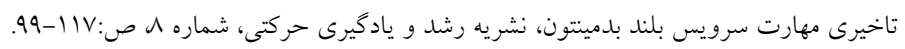

4. Zetou, E., et al., 2012, The effect of self-talk in learning the volleyball service skill and self-efficacy improvement, Journal of Human Sport \& Exercise,7(4):p.794-805.

5. Buchanan, J.J. and N. Dean, 2014, Consistently modeling the same movement strategy is more important than model skill level in observational learning contexts. Acta psychologica,. 146: p. 19-27.

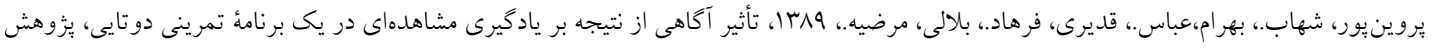

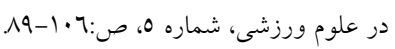

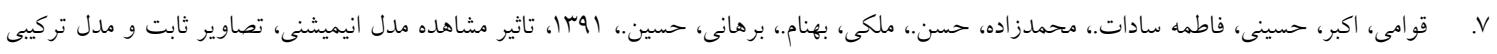

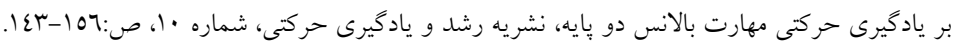

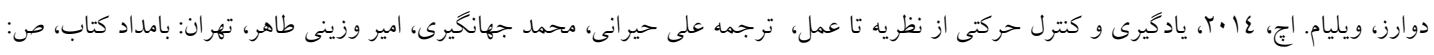

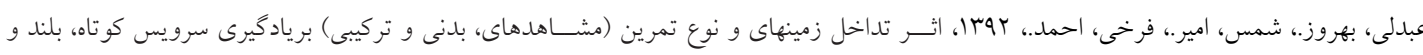

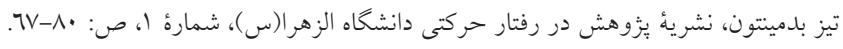


10. Somogyi, E., et al., 2015., The roles of observation and manipulation in learning to use a tool. Cognitive Development,. 35: p. 186-200.

11. Boutin ,A., et al., 2010., Role of action observation and action in sequence learning and coding. Acta Psychologica,. 135(2): p. 240-251.

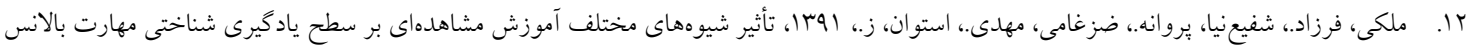

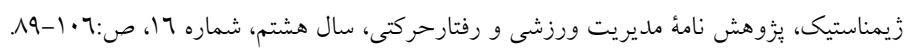

13. Hardy, J., K. Begley, and A.W. Blanchfield,2015, It's good but it's not right: instructional self-talk and skilled performance. Journal of Applied Sport Psychology,. 27(2): p. 132-139.

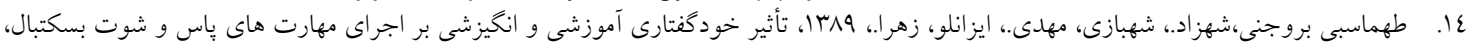

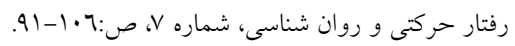

15. Hatzigeorgiadis, A., et al., 2013, Self-talk and Competitive Sport Performance. Journal of Applied Sport Psychology, 26: 82-95

16. Zourbanos, N., et al., 2013, The effects of motivational self-talk on self-efficacy and performance in novice undergraduate student, The Sport Psychologist, 27, 171-176.

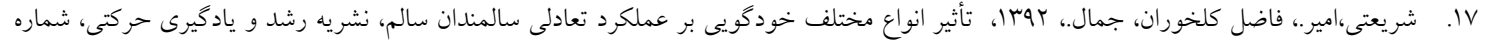

$$
\begin{aligned}
& \text { آl }
\end{aligned}
$$

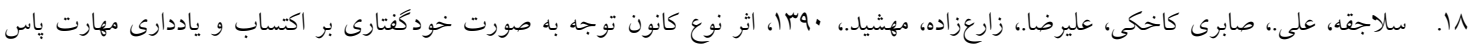

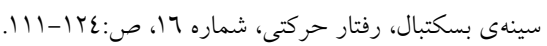

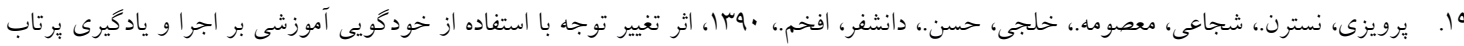

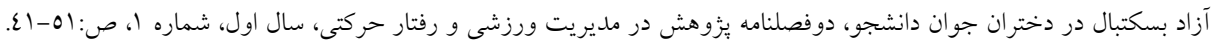

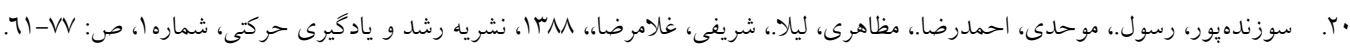

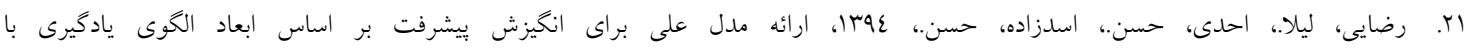

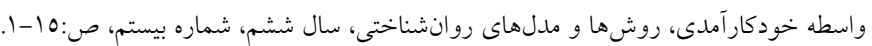

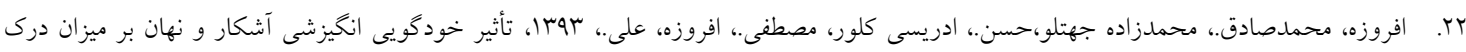

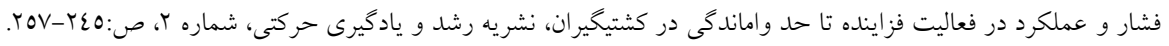

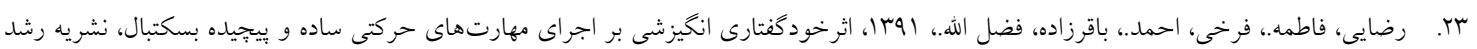

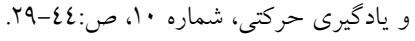

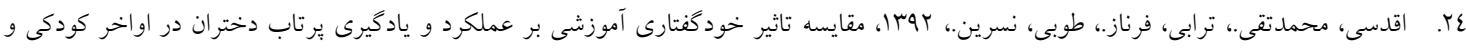

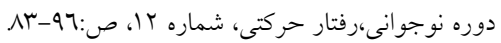

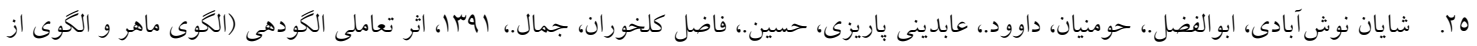

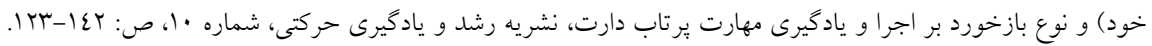

26. Palmer, S.L., 1992, A comparison of mental practice techniques as applied to the developing competitive figure skater. The Sport Psychologist,. 6(2): p. 148-155.

27. Meyers, A.W., Sch lesser, R., 300ke, C.J., \& Cnvillier, C, 1979, Cognitive contribntions to thedevelopment of gymnastics skills. Cognitive Trapy and Research, 3, 75-84.

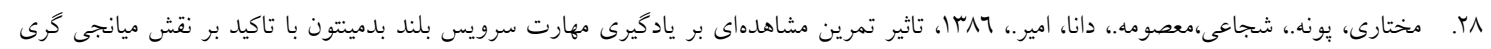

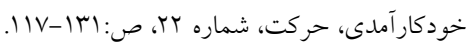

